https://doi.org/10.22364/hssl.27.1.03

\title{
DEBATING OVER EUROPEAN UNION'S FUTURE: RE-POLITICISATION AND BACK TO DIRECT DEMOCRACY?
}

\section{Nellie Munin}

LL.D

\begin{abstract}
:
The article analyses the recommendations of the Van den Brande report titled: Reaching Out to EU Citizens: A New Opportunity: 'About us, with us, for us' (published October 2017) in light of three previous policy statements by the EU Commission: the Five Presidents Report (2015), the White Paper on the Future of Europe and the State of the Union Address (2017). It tries to assess whether the sequence of these policy statements and the $\mathrm{VdB}$ report reflects a chronological EU shift from 'de-politicisation' to 're-politicisation', whether VdB report reflects an innovative approach towards this challenge compared to these previous statements and whether acting according to it, particularly with regard to intensifying the direct dialogue with EU citizens, may improve the democratic nature of the public discourse and of the decision-making processes regarding EU's future.
\end{abstract}

Keywords: EU, democratic deficit, direct democracy, de-politicisation, re-politicisation.

\section{Introduction}

The crises with which the EU is struggling in recent years seem to intensify EU's citizens' frustration regarding what is known as the 'democratic deficit', namely: the remoteness of ordinary citizens from decision-making centres and processes. This, in turn, triggers nationalist and Euro-sceptic feelings. ${ }^{1}$

The 'democratic deficit' encompasses a procedural aspect, regarding the due democratic representation of the citizens' opinions in a supranational regime (e.g. Majone 1998; Moravcsik 2002; Munin, 2016a), establishing its 'legitimacy' or rather 'illegitimacy' (e.g. Scharpf, 1999; Schmidt, 2006; Hix, 2008; Scharpf, 2013; Tsoukalis, 2016). It also holds a substantive aspect, referring to the 'choices the democratic politics can make' (Bartl, 2015a, p. 18; See also Durach, 2012, pp. 48-9).

1 These feelings are turned not only towards the EU, but also towards national governments acting according to their international commitments in the EU, instead of being more 'responsive' to their voters, e.g., Kriesi (2014); Hobolt (2015). 
Realising that citizens' participation in decision-making processes should be enhanced, EU institutions take growing efforts to close their information gap: modern technology facilitates better access to EU documents; platforms for direct dialogue between EU citizens and leaders are set; official reports appeal to EU citizens. EU institutions strive to intensify the involvement of EU Parliament (Hereby: EP), the only institution the members of which EU citizens directly elect, in decision-making processes, ${ }^{2}$ and to enhance dialogue with national parliaments; they initiate public events where EU citizens can meet decision makers and discuss with them.

Nevertheless, these efforts are proved to be insufficient to decrease EU citizens' mistrust in the EU and its institutions.

Luc Van den Brande, a Flemish politician enjoying rich national and EU experience, addresses both these procedural and substantial challenges in his report to the president of EU Commission, dated October 2017: Reaching Out to EU Citizens: A New Opportunity: 'About us, with us, for us'. (Hereby: VdB report).

Turning to a political expert for advice on this issue may reflect EU's shift from 'technocratic-driven de-politicisation - which had assumed that good policy performance... and quality procedures... was sufficient for legitimacy' (Schmidt, 2017, p. 3; see also Bartl, 2015, pp. 6-7), to seeking political legitimacy.

This article examines VdB report's recommendations in light of three previous EU Commission's attempts to reach out to EU citizens: The Five Presidents Report (2015) (Juncker, 2015, hereby: Five Presidents Report), The White Paper on the Future of Europe (2017) (Juncker, 2017, hereby: White Paper) and the State of the Union Address given by EU Commission's President in September 2017 (Juncker, 2017a, hereby: State of the Union Address).

These attempts are criticised (e.g., Munin, 2016; Munin and Matthee, 2018) for the gap between their rhetoric and their real effect, enhancing the sense of procedural and substantial 'democratic deficit' among EU citizens.

This article tries to assess whether the sequence of these policy statements and VdB report reflects a chronological EU shift from 'depoliticisation' to 're-politicisation', whether $\mathrm{VdB}$ report reflects and innovative approach towards this challenge compared to these previous

2 Some scholars stress EP's growing importance, e.g. Hix and Hoyland (2013); Fasone (2014); Dinan (2015); Héritier et al. (2016). Others mark its growing use as an EU platform for populists 'to speak to their national constituencies', while nonmajoritarian EU institutions do not experience the same degree of politicisation, e.g. Schmidt (2017) p. 9. 
statements and whether acting according to it, particularly with regard to intensifying the direct dialogue with EU citizens, may improve the democratic nature of the public discourse and of the decision-making processes regarding EU's future.

\section{'De-politicisation' and 'Re-politicisation'}

EU institutions establish their supranational authority by allegedly adopting a de-politicised approach. Focusing on the establishment, development and functioning of the internal market as a major aim, "[g]oals are presented as noncontroversial, and solutions are presented as based on scientific knowledge.' (Mańko, 2017, p. 35).

This rational approach builds on a strong bond of such knowledge (claimed to be held by EU institutions, particularly by the Commission) and governance: "the relationship between governance and knowledge is one of dependence, when the two co-produce each other in a dynamic and evolutionary fashion.' (Bartl, 2015, p. 4, emphasis original). Since the EU is an artificial creation, formed by legal means, 'just as the normative objectives infuse knowledge, so does the accumulated knowledge, both cognitively and normatively, shape the creation of new normative objectives.' (Bartl, 2015, p. 4). This mutual fertilization is reflected in the process of EU legislation, directed and mastered by EU officials. (Ziętek, 2012, p. 282, translated by Mańko, 2017, p. 37). The decisiveness of this process to internal market development is stressed by the president of EU Commission, urging in the State of the Union Address: '[w]e must now work together to turn proposals into law, and law into practice.'

This technocratic or 'functional' approach is criticised for effectively preventing a vivid political discourse among EU citizens, turning them passive. 'Social and economic issues which would otherwise be politically contestable $\mathrm{e}^{3}$ become the object of uncontested technocratic assumptions allegedly following from a body of commonly accepted knowledge.' (Mańko, 2017, p. 34).

Critiques thus perceive this technocratic approach as 'symbolic violence' against traditional legal knowledge (deemed irrelevant to solve 'modern' problems), political actors (undermined on grounds of lack of expert knowledge), and human subjects (treated merely as means to an end: smooth market functioning, factoring out all other human

3 For example, this form of decision making prevents thorough discourse regarding the feeling of many EU citizens that the capitalist industrial society takes advantage of the EU supranational structure, to emancipate itself from the social market economy with regard to issues such as employment and distributive social policy. Habermas (1996) p. 418; Böckenförde (2017b) p. 351. 
dimensions, e.g. spiritual, ethical) (Mańko, 2017, pp. 42-3), nourishing the substantial 'democratic deficit'. The supranational structure of decisionmaking, underlining EU's procedural democratic deficit, highly facilitates this process.

To recover the 'democratic deficit' scholars ${ }^{4}$ thus recommend 'repoliticisation' of this technocratic approach. Questioning the system and considering 'whose interests must the law articulate, serve and protect' already marks a certain degree of 're-politicization' (Mańko, 2017, p. 61).

Recently, 'the increasing politicisation of EU institutions' is recognised in the literature, although EU theories of integration have done little so far to incorporate it into their considerations of EU governance as a whole (Schmidt, 2017, p. 11). Hence, what scholars describe as 'de-politicisation' may be alternatively understood as preferring political interests of EU players over national and regional ones.

If this is correct, 're-politicisation' may be understood as merely changing the political equilibrium in favour of national, regional and personal political interests of EU citizens.

The importance of citizens' participation in politics, to balance the opinion of elite leadership, has been long recognised. Zaller (1992, p. 331) provides three justifications for it: people have a right to be involved in governance; political participation is a value in itself; and citizens' involvement provides a check on the government's tendency to go 'astray and become . . . overbearing or worse.' Hochschild (2013) stresses the importance that citizens would not follow elite opinion leadership automatically, particularly when leaders' assertions are empirically unsupported or morally unjustified. However, sometimes both citizens' and government's positions on a certain issue may be only assessed hindsight, which 'makes one's normative stance uneasily hostage to fortune'. (Zaller, 1992, p. 540).

The next sections assess whether $\mathrm{VdB}$ report recommends proceeding towards 're-politicisation', in comparison to the previous EU Commission's policy statements examined.

\section{Section 1: Win the People's Hearts}

Van den Brande (2017, p. 6) stresses one major reason for the ongoing 'democratic deficit': the lack of EU citizens' 'emotional engagement' with the EU, and of a feeling 'that they are fully part of the European project'. He argues that EU institutions communicate to citizens mainly rational information, based on facts and figures, neglecting the complementary

4 Bartl (2017) and Mańko (2017) examine these insights in the context of private law. 
need to win their hearts. It seems to echo the perception that 'symbolical identification with the EU... could help build up support'. (Durach, 2012, p. 9). This approach constantly competes with the EU's 'instrumental' approach, relying on a 'utilitarian' thesis, assuming that citizens' support depends merely on EU performance and cost/benefit considerations. (Scheuer and Schmitt, 2009; Siagalas, 2010).

The disadvantage of the 'utilitarian' approach is that 'support for integration becomes highly dependent on short-term outputs and benefits'. (Kumlin, 2009, p. 410; Durach, 2012, p. 9). VdB report assumes that emotional identification may establish a more stable, long-term support. The literature supports this assumption. The power of emotions in politics is decisive, since power relations and social hierarchies condition human emotions (Gross, 2006). Political trust builds on the emotional sense of identity and community (Harteveld et al, 2013). Affective support complements instrumental support, encompassing emotional responses, identity-related factors, and perceived threats to the nation, thus being more stable and stronger. (Durach, 2012, p. 9).

EU leaders were already aware of emotions' importance while drafting the three policy statements examined:

The Five Presidents Report (2015) - was written in the height of the financial crisis. It suggests that recovering the financial crisis and immunising the EU from future financial crises depends on deepening the financial and monetary integration among its Member States, to create a full monetary union, followed full fiscal, economic and finally political union. Generally, this is a very 'technocratic' document, mainly consisting of what $\mathrm{VdB}$ report would perceive as rational information, highly advocating for the major 'functional' aim: strengthening the internal market. Nevertheless, it includes some marginal attempts to invoke citizens' emotional empathy, using a simpler language:

\section{The House Allegory}

The report uses an image of a house that belongs to all EU citizens, shared by them and sheltering them from external storms, in need for repair or completion, to the general benefit (Juncker, 2015, pp. 4-5). However, this allegory seems misplaced in its general, rational and technical context, and thus unreliable (Munin, 2016).

\section{Invoking Mutual Pride at the Euro}

The report describes the success of establishing a strong currency, being 'the second most important currency in the world' (Juncker, 2015, 4). However, the pride potentially invoked by this statement is used as leverage to advocate for intensified market integration: 'the world's second 
largest economy cannot be managed through rule-base cooperation alone', but 'would require Member States to accept increasingly joint decisionmaking on elements of their respective national budgets and economic policies.' (Juncker, 2015, p. 5).

The White Paper (March 2017) published two years after the Five Presidents Report, takes a far greater effort to appeal to EU citizens (Munin and Matthee, 2018). Thus, for example:

- It is written in a far more popular language than the Five Presidents Report.

- It depicts five proposed scenarios for EU's future very briefly and schematically, for the citizen's choice.

- It uses graphic and oral allegories to describe the relationships between the EU and its citizens, e.g., a repetitive graphic motive of a flock of birds that may symbolize a strong, interdependent alliance.

- Building on the emotion of fear

- It recalls World War II horrors, to stress a shared destiny and mutual commitment to prevent future wars, by strengthening the EU.

- It reminds the readers of their shared responsibility to leave a better place of living for their offspring.

- To enhance solidarity

- The Commission takes full responsibility for its failures and admits them.

- The document reflects optimism, criticising or blaming EU citizens and national institutions for the current situation more moderately and implicitly, compared to the Five Presidents Report.

- It invokes mutual pride by praising the EU project and its achievements hitherto.

Nevertheless, these efforts are meant to promote the 'functional' agenda: enhancement of the EU project, which the document strongly advocates for.

In the State of the Union Address (September 2017), to invoke citizens' pride Juncker specifies the recent achievements of Commission's policy: stabilising the internal market - the project underlining the 'functional' approach, praising EU institutions, which 'played their part in helping the wind change.' Building on EU citizens' sense of fear, Juncker proposes to opt for to 'a Europe that protects, a Europe that empowers, a Europe that defends.' Declaring his love to the EU could have invoked instinctive emotional identification, had it not been immediately followed by 'functional' reasoning. 
At the end of this statement, Juncker repeats the house allegory, indicating there is still much repair work to do, adding another picturesque, populist image, of sailing the EU boat together.

Substantially, however, Juncker's determinant ruling out of the White Paper's five scenarios in favour of a sixth one: full 'functional' market integration, undermines the impression of sincere appealing to citizens' hearts, potentially invoked by the White Paper or by this Statement.

The Emotions Invoked

VdB report's assumption that EU citizens' emotions are not addressed is thus inaccurate: the statements examined reflect juggling between citizens' emotions of pride, fear and guilt (e.g. Munin and Matthee, 2018, pp. 13-15). However, citizens' emotions are manipulated to impose the Commission's 'functional agenda' by carrots and sticks, instead of treating EU citizens as sincere partners for a dialogue that would foster true and deep emotions of belonging, involvement in the project and care.

\section{Simplicity of the Message?}

Van den Brande $(2017$, pp. 6, 26) implicitly criticises the amount of information the EU communicates to its citizens, highly recommending simplicity of messages. The brief and schematic description of the five proposed scenarios in the White Paper, and the determinant 'mantras' of the State of the Union Address, reflect the shortcomings of this approach: they do not equip EU citizens with enough information to seriously weigh these options comparatively, to make an informed choice.

The choice between these two tactics may be further challenged by Durach's finding $(2016$, p. 8 ) that low level of knowledge and little understanding of EU politics yield citizens' indifference, while highly informed and knowledgeable Europeans tend to develop ambivalence towards the EU.

\section{Assumptions as Shortcuts}

Instead of listening carefully to EU citizens and taking their opinions and suggestions into consideration, to make them feel 'that they are fully part of the European project' (Van den Brande, 2017, p. 6), assumptions are used as shortcuts to policy decisions. E.g., the 'technocratic' assumption that intensifying market integration is necessarily the best way forward. The White Paper pretends to question it, but the later State of Union Address reinforces it.

Using such shortcuts "both restricts the space for democratic determination of what... Europeans want and constrains the possibility to control for the possible mistakes (biases) in those assumptions...' (Bartl, 2015, p. 4). 


\section{Section 2: Enhanced Dialogue with Entities Representing EU Citizens}

\section{'Open Government'}

Van den Brande $(2017$, p. 6) stresses the importance of 'acting with a mindset of 'open government', appealing to citizens as an equal partner.' This recommendation encompasses a procedural aspect, i.e. enhancing the dialogue with entities representing EU citizens (discussed in this section), and the direct dialogue with EU citizens (discussed in the next section), and a substantial aspect, discussed in both sections.

\section{Ambivalent approach}

$\mathrm{VdB}$ report (Van den Brande, 2017, p. 10) recognises the 'need to engage more with Member States in developing a European vision.' However, by the same token it implicitly blames them for 'nationalising the successes and Europeanising the failures of the EU' (emphases original) and for not collaborating fairly with EU institutions in communication with the public.

It recognises the importance of intensifying the involvement of European Parliament in the decision-making process, stressing its 'special opportunity to interact from a bottom-up perspective with citizens', while at the same time doubting its capacities by mentioning the low turnout by which the EP is elected (Van den Brande, 2017, p. 24) and questioning ' $[\mathrm{t}$ ] he election of Members of the European Parliament (MEPs) on the basis of Member State determined constituencies', calling for creating '[a|n EUwide electoral constituency'. (Van den Brande, 2017, p. 23). ${ }^{5}$

Regarding this ambivalence, or implied criticism, towards entities representing EU citizens, VdB report does not mark any progress compared to the previous statements:

The Five Presidents Report - on the one hand praises the gradually growing participation of the European Parliament by engaging in 'economic dialogues' with the Council, the Commission and the Eurogroup, and the intensification of its dialogue with the national parliaments, calling for further intensification of these collaborations. (Juncker, 2015, pp. 17-18).

5 This need, in itself, is supported by scholars, e.g.:

'[T]he European Parliament cannot represent what does not exist: The European people; and it cannot mirror something that does not (yet) exist: A European political public that takes shape beyond national boundaries around the decisive questions of European politics.' Böckenförde (2017) p. 359. 
On the other hand, it implicitly criticises the EP by recommending it to 'organise itself to assume its role in matters pertaining especially to the Euro area.' (Juncker, 2015, p. 17).

While realising the importance of co-operation with the Member States on the EU project, it carries some counter-productive, implicitly criticising messages, stressing that democracy and stronger democratic participation implies enhanced accountability (of EU citizens and Member States) (Juncker, 2015, p. 5) and that enhanced market integration would imply further delegation of powers from national to EU level, as well as a shift the focus from the Members' needs to EU priorities. (Juncker, 2015, p. 9).

In his opening message to the The White Paper, the President of EU Commission expresses his expectation for 'a broad debate... including the European Parliament...' (Juncker, 2017, p. 3). The White Paper scenarios foresee the enhancement of EP's participation in decision-making processes (e.g. scenario 5 - final say on international trade agreements by 2025; supporting the European Investment Bank in boosting investment in the EU; hosting meetings regarding the debate over the future of the $\mathrm{EU}$ ). (Juncker, 2017, pp. 24, 25, 26 respectively).

At the same time, Scenario 1, titled 'carrying on' (Juncker, 2017, p. 17) implicitly criticises the functioning of national and regional parliaments, by describing them as delaying the ratification process of international progressive trade agreements, successfully negotiated by EU Commission.

This repetitive ambivalence, that may be interpreted as 'coexistence of positive and negative evaluations of a single object' (Stoeckel, 2012, p. 25), undermines the credibility of Commission's declared position, of striving to enhance collaboration with national and regional authorities, and with the EP. Indirectly, it may undermine citizens' trust in their national political institutions, and local and regional elites, through which trust in the EU is driven. (Durach, 2012, pp. 17, 38; De Vries, 2018).

\section{Co-operation - to promote EU agenda}

The State of the Union Address reflects that Juncker supports intensified involvement of the EP, national parliaments and civil society at national, regional and local levels in EU's decision-making process, as long as it serves 'the work on the future of Europe:'

- Addressing the controversy with the Member States on the Asylum policy, Juncker suggests a compromise, based on negotiations. He stresses, however, that it will be acceptable 'as long as the outcome is the right one for our Union.'

- While 'open government' would presume deciding the agenda together, Juncker specifies the priorities forward, starting every suggestion with the words 'I want.' The five priorities he specifies 
all serve the 'functional' purpose of facilitating the internal market: strengthen trade agenda and industry; lead the fight against climate change; enhance cyber protection; control migration.

\section{Broadening and deepening the dialogue: procedural innovation}

$\mathrm{VdB}$ report suggests considerable, coherent expansion of the dialogue circle, to include Mayors and councillors, the Committee of the Regions, the European Economic and Social Committee, and expansion of democratic functions of representative institutions, e.g.:

- The European Parliament: using its elections campaigns to discuss EU matters; open its doors on regular basis to EU citizens and discuss their concerns in a joint plenary session with EU Commission; organise 'question time' sessions for EU citizens.

- National and regional parliaments: providing them with a possibility to show a 'green card' for legislative proposals put forward by citizens, compelling the Commission, following a proposal submitted by one third of the national and regional parliaments, to examine the proposal for EU action in any given policy area. (Van den Brande, 2017, pp. 23, 24, 27).

These recommendations are procedurally innovative. However, even if adopted, their success would depend on complementary, substantial replacement of EU's ambivalence towards the entities representing EU citizens, with 'equal partners' treatment: sincere weighing of the interests they represent against 'functional' EU interests.

\section{'Multilevel Community'}

\section{A New Kind of Political Thinking?}

$\mathrm{VdB}$ report recommends the adoption of 'a new kind of political thinking', inspired by the Charter for Multi-Level Governance of the Committee of the Regions (European Committee of the Regions, 2014),

'which refers to the principles of togetherness, partnership, awareness of interdependence, multiactor community, efficiency, subsidiarity, transparency and sharing of best practices, enabling the development of a transparent, open and inclusive policymaking process, promoting participation and partnership, respecting subsidiarity and proportionality in policymaking and ensuring maximum fundamental rights protection at all levels of governance to strengthen institutional capacity building and investing in policy learning among all levels of governance.' (Van den Brande, 2017, pp. 11-12).

This list implies some deficiencies, or lacks, of the current system, some well reflected in the three examined statements, e.g.: 
The Five Presidents Report - recognises the interdependence among EU Member States and between them and EU institutions, reinforced by their financial integration, but insufficiently respects it in terms of sharing decision making with national authorities. (Munin, 2016).

The White Paper - allegedly respects the principles of togetherness, partnership, transparency, enabling the development of a transparent, open and inclusive policymaking process, promoting participation and partnership, by initiating an EU-wide dialogue, allegedly compatible with the acknowledgment that '...only an awareness of clear future perspectives can provide the necessary confidence in the Union's future'. (Van den Brande, 2017 , p. 8). However, the strong dissonance between this message and the confession by the President of EU Commission, in his State of Union Address that the Commission still highly supports full market integration, casts a doubt whether EU institutions seriously refer to this discourse as 'a disempowered dialogue of emancipated people' (Habermas, 2008; See also Van den Brande, 2017, p. 7).

'Inclusiveness' is used in the State of the Union Address to portray a tighter 'functional' alliance, where all Member States participate in Schengen arrangements, adopt the Euro and join a banking union, have a European Minister of Economy and Finance, a European intelligence unit, establish a European Defence Union, merge the functions of the Presidents of the Commission and of the Council, agree on a European Social Standards Union and maintain enlargement perspective for the Western Balkan.

$\mathrm{VdB}$ report does not suggest how to change the interpretation of the Charter's words to meet the expectations of EU citizens and Member States for a sincere, open dialogue.

\section{Identity and Values}

Van den Brande (2017, p. 10) advises to grasp EU institutions as one layer of a 'community',

'which embraces the local, regional, national and international contexts that individuals live in to create a common public space, within which individuals can act together on a value-based foundation. The Union, in this context, needs to add its own identity and shared values to existing regional and national notions of belonging, which reflect the concept of multilevel citizenship. The Charter of Fundamental Rights of the European Union and Article 2 of the Lisbon Treaty provide exactly that.' (Emphasis added).

\section{Values}

One could assume that most EU citizens, national governments, local authorities and EU institutions would embrace universal values included in 
the legal documents mentioned. Nevertheless, the different motivation of the parties (Bartl, 2015, p. 10) seems to imply different meanings of these values, although justified on universal grounds. ${ }^{6}$

'For me - Juncker reveals in his State of the Union Address - Europe is more than just a single market. More than money, more than a currency, more than the Euro. It was always about values.' This declaration is allegedly compatible with the spirit of VdB report's recommendation. Alas, it is only an opening remark to his description of a future EU vision: the 'functional' project, which, according to Juncker, must entail the three basic values: freedom, equality and the rule of law. To illustrate freedom, he mentions the alternative regime that Central and Eastern European Member States experienced before 1991, invoking fear. He interprets equality as implying: vaccinations to all; a common labour authority; Unionwide consumer protection. By the rule of law, he means respecting EU law and CJEU judgments. He reiterates that respecting these principles would lead to a more democratic union, without explaining how. Needless to say, in a national context or individual eyes, these values may bear different meanings.

\section{Democracy}

A major perception-gap between the EU, its Member States and citizens, focuses on the substance of 'democracy'. ${ }^{7}$

\section{EU's Superiority}

$\mathrm{VdB}$ report does not specify the recommended division of powers between the different layers of the EU community.

It recognises the limits of EU responsibilities, admitting they are defined by the Member States - only to argue that criticising the EU for issues beyond its responsibility is unjustified. ${ }^{8}$ (Van den Brande, 2017, p. 12).

6 See, e.g. Perju (2018) pp. 432-433; the interpretation of 'justice': Bartl (2015), addressing the different interpretative motivation of these parties in the context of private law.

7 In general, the perception of democracy seems to change over time with regard to international organisations, increasingly seen as objects of democratic demands for transparency and accountability, while representational concerns become more relevant justifications for demanding greater participation in them. Dingwerth et al. (2015).

8 Such criticism indicates citizens' information gap: 'as long as the average citizen is poorly informed and has a low level of political interest, he or she does not clearly distinguish the achievements and shortcomings of the different layers of EU governance,' thus judging by the overall political performance. Durach (2012) p. 17). 
It further contends:

'The Lisbon Treaty allows for the EU to be described as a "polity of states and citizens, in which the citizens are entitled to participate both in the national democracies of the countries and in the common democracy of the Union'... it is the citizens themselves who are, ultimately, the owners of EU democracy, leading to Europeanisation through democratisation.' (Van den Brande, 2017, p. 11).

This statement may be interpreted in one of three ways:

- as recognising the importance of the States in EU structure and politics (like Böckenförde, 2017b, p. 358), since EU citizens elect their national governments;

- as reflecting the perception of 'bi-directional' flow of authority between EU institutions and States (like Weiler and Trachtman, 1996-7, p. 374), which some criticise for leading to an 'ill-advised celebration of the clash among competing claims to authority' (Perju, 2018, p. 416); or

- as a call for a direct dialogue of EU institutions and the citizens, circumventing the Member States.

Some elements of $\mathrm{VdB}$ report reveal that eventually, it supports EU supremacy. This may not come as a surprise, as the Commission ordered the report. Thus, for example:

- Van den Brande (2017, p. 11) calls for considering the EU not only as a socio-economic endeavour, 'but also as a community of destiny, life, purpose, responsibility and multicultural learning, as well as a meeting place of multiple identities', namely as an alliance embracing all fields of its citizens' lives, in line with the Commission's vision on comprehensive integration.

- Criticising the contradicting messages the EU and the Member States often send to their citizens, Van den Brande (2017, p. 11) contends that EU Member States 'are at the same time part of a common European space; 'splace' as the cross-fertilisation between 'place' and 'space'.'

- Van den Brande (2017, p. 17) stresses that 'ilt is no longer possible for the EU to be explained in terms of the traditional, so-called Westphalian system of isolated responsibility of Member States. The Member States are pillars of the Union's project.' (Emphasis added).

This is a far-reaching statement, particularly for those EU citizens, scholars and States who perceive the Westphalian system of nationalstate as a mechanism protecting the space of democratic self-government and immunising it from supranational interference (the German Federal 
Constitutional Court, 1993; Paris, 2017; Perju, 2018, p. 414). ${ }^{9}$ To a certain extent, it contradicts the former references of the report to the EU as a layer of a community, which needs to add its own identity and shared values to its existing ones, and its alleged recognition of EU citizens as the source of EU's legitimacy and power.

On that issue, the VdB report's approach does not mark a change compared to the approach of the three previous statements:

In the State of the Union Address Juncker announced the establishment of a Subsidiarity and Proportionality Task Force "to take a very critical look at all policy areas to make sure we are only acting where the EU adds value,' allegedly in line with the Charter for Multi-Level Governance recommendation. However, as long as Commission officials take this decision, it might be biased in favour of Commission's interests. The Five Presidents Report openly linked recommended market integration with further delegation of powers from the Member States to the EU. The White Paper implied it in the context of advanced integration scenarios.

\section{Elections' financing}

Under the headline of 'democracy', Juncker in the State of the Union Address, reiterates with regard to financing political parties in the next elections: ' $[w]$ e should not be filling the coffers of anti-European extremists,' i.e. implies taking advantage of EU's dominant position, to bias the democratic process in favour of their supporters.

\section{Citizens Participation}

The VdB report's sub-title: 'about us, with us, for us' echoes Abraham Lincoln's definition of democracy (1863) as 'government of the people, by the people [and] for the people'. However, the report's choice of words: 'about us, with us' rather than 'of us, by us' reflects its ambivalent approach towards the citizens' effective participation in the decision-making process, trying to please them and EU Commission at the same time.

\section{Narrowing down the scope of discussion}

$\mathrm{VdB}$ report's suggestion for open and inclusive policymaking process, promoting participation and partnership seems to overlook two major deficiencies in EU's public discourse, perceived as core causes to the substantial 'democratic deficit':

'First, the range of topics open to democratic debate in the EU is narrower thanks to the EU functional design (horizontal substantive

9 For elaboration on the players and relative powers in the post-Westphalian arena see: Terhalle, (2016). 
democratic deficit). Second, the proportion of the debate, which we could genuinely describe as being political, is declining as a result of the de-politicisation of EU goals, underpinned by a massive accumulation of allegedly apolitical expert knowledge (vertical substantive democratic deficit).' (Bartl, 2015a, p. 1).

Thus, by introducing the White Paper's five scenarios, the Commission narrows down the discussion, a priori excluding other options. The same tactic is used in the Five Presidents Report, which determinately advocated for further market integration, and by the State of the Union Address, where Juncker says, for example: '[w]e only had two choices. Come together either around a positive European agenda or each retreat into our own corners. Faced with this choice, I argued for unity.' Then, he limits the time frame: '[w]e now have a window of opportunity but it will not stay open forever.' 10

In sum, the three statements reflect that the Commission does not seem to perceive the EU as a link in a chain, and instead of 'adding its own identity and shared values to existing regional and national notions of belonging' as e VdB report recommends, imposes its 'functional' positions on EU citizens, neglecting regional and national notions of belonging.

Following this VdB report's advice may thus mark an EU's substantial change of approach.

\section{Section 3: Direct Dialogue with EU Citizens}

'Citizen's political participation and governing elite's responsiveness' (Schmidt, 2017, p. 3) is one important component of EU's legitimacy. ${ }^{11}$ However, Bartl (2015, p. 12) ${ }^{12}$ suggests that during EU evolvement, the perception of individuals substantially changed, from 'customers' that should be well served by the system, to 'vehicles for achieving a greater objective - market integration.' Moreover, EU institutions build their policy and practice on assumptions with regard to what is good for EU citizens, which may be false for many of them and lead to market failures, such as regressive redistribution, from poor to rich (Bartl, 2015, p. 14). Realising that this approach of EU institutions needs to be changed, Van den Brande

\footnotetext{
${ }^{10}$ Framing consultations narrowly to avoid discussion on broader implications of suggested EU policy is a tactic the Commission used in other fields as well, e.g. private law. Bartl (2015) p. 24; Bartl (2015a) p. 12).

11 The other components being policy effectiveness and performance and the quality of governance processes: efficacy, accountability, transparency, inclusiveness and openness to interest consultation. Schmidt (2017).

${ }^{12}$ Bartl addresses this change in the context of private law. Nevertheless, it seems to be valid in the broader context as well.
} 
(2017, p. 11) recommends that EU citizens would be 'given the capacity to decide their future priorities themselves, by providing them with the tools and faculty of choice.'

If followed, this could mark a progress compared to the previous statements' approach.

\section{Reaching out to Young Citizens}

Van den Brande (2017, p. 20) indicates that more than $40 \%$ of Europeans are under the age of 35 . He assesses that ' $t$ they usually tend to be more 'Euro-critical' than 'Eurosceptic' and are often aware of the advantages of the Union, but may well advocate alternative models of EU governance.' This is why Van den Brande (2017, pp. 8, 27-8) stresses the particular importance of reaching out to them, making better use of the social media and educational programs. ${ }^{13}$

This seems to be a lesson drawn from the Brexit referendum: most supporters of the Brexit were the elder citizens, while many youngsters, objecting it, refrained voting (Time, 2016). It marks an innovation compared to the three previous statements, which convey a uniform message to all addressees.

The report calls for implementing the Council resolution on the structured dialogue and the future development of the dialogue with young people in the context of policies for European cooperation in the youth field, post 2018 European Council. (EU Council, 2017). This resolution relied on broad consultation with EU youngsters. It includes some recommendations to enhance youth participation in the EU project, by improving their access to quality and critical information, fostering communication among young citizens from different countries, education, mobility programs etc.

Nevertheless, $\mathrm{VdB}$ report does not elaborate on the substance of the message that might appeal to them.

Additionally, the report does not elaborate on any particular strategy to approach the rest $60 \%$ of EU citizens. Doing so, it overlooks (as the other statements examined) assessments that the heterogeneity of public preferences in the EU casts a serious doubt over the success chances of any one-size-fits-all approach to Euroscepticism. (De Vries, 2018).

\footnotetext{
${ }^{13}$ The report particularly recommends extending the use of ERASMUS program. However, studies show that it does not necessarily strengthen students' EU identity and can even have adverse effect on it. E.g. Sigalas (2010a).
} 


\section{Means: Aiming at the Social Media}

Van den Brande (2017, pp. 16-17) recognises the advantages of the digital society and the social media to interactively reach out to the young EU citizens: facilitating information reception, while at the same time turning each user into a potential producer of information. Allowing for multidirectional communication, for crowdsourcing, providing fast capacity for reaction.

Unlike the other two statements, the White Paper encouraged an interactive dialogue with EU citizens, both through the internet and in face-to-face meetings, allegedly a step in the direction $\mathrm{VdB}$ report recommended. However, it used the 'one size fit to all' model; it is unknown to what extent participation of young citizens in this debate was effectively triggered; people's voice was not translated into pragmatic change of approach by EU institutions and in any case, $\mathrm{VdB}$ report foresees a more comprehensive and systematic interactive dialogue.

\section{Deficiencies of the Social Media}

Van den Brande (2017, p. 16) warns that while the social media uniquely facilitates the enhancement of direct democracy, it involves risks such as the dissemination of fake news, 'alternative facts' and myths. Thus, anti-democratic forces may misuse it. Furthermore, it tends to lookout for sensationalist topics to keep the public interest high, compromising quality and trustworthiness compared to traditional media, and 'paving the way to populist and extremist trends.'

EU institutions and scholars (e.g. Anderson, 2014; Müller, 2016; Bugarič and Kuhelj, 2018) share this concern. Social media may reflect the competition between national and supranational powers over EU citizens' hearts, but at the same time it may facilitate 'vertical de-fragmentation of political and constitutional transformations at the domestic level' (Perju, 2018, pp. 407-8), or an 'authoritarian backsliding' (e.g. Pech and Scheppele, $2017)^{14}$ of domestic governments, invoking the question whether - and to what extent - EU institutions can or should interfere to defend the rule of law and restore the normative integrity of the Member States so affected. (Perju, 2018, pp. 419-430).

Yet another challenge to the democratic discourse through the social media lies in 'the capacity of the majority of the population to find, access, understand and evaluate the flow of online information.' (Van den Brande, 2017, p. 16).

\footnotetext{
${ }^{14}$ Some scholars (e.g. Perju (2018) p. 421; Bugarič and Kuhelj (2018)) regard the risk of 'authoritarian backsliding' in Central and Eastern European countries as particularly threatening.
} 
Despite these potential deficiencies, the report strongly recommends that the EU opt for 'digital democracy', stressing in particular the importance of 'big data' such networks can uniquely handle.

\section{Means: Bottom-up Approach}

Van den Brande $(2017$, pp. $23,27,28)$ recommends to replace the current, lobbyist-dominated character of vertical civil dialogue with direct inputs from the general public, i.e. bottom-up agenda-setting, by:

- turning the existing European Citizens Initiative (ECI) into a platform of direct exchange between citizens and EU Commission, handled by a single entity.

- conducting a regular dialogue with churches, philosophical and non-confessional organizations, and members of all accredited organisations.

- reaching out to 'non-organised citizens' and organised movements belonging to different groups in the society, to initiate decentralised citizens assemblies, the outcomes of which would be informed to the European Parliament.

- developing a new scheme to facilitate exchanges and networks for politicians and social activists.

- striving for the direct election of a single President of one EU institution, such as the European Council, the EU Commission or the President of a new functional constellation.

- establishing a European Foundation co-financed by the EU, the Member States and the private sector to foster better understanding between the EU and its citizens.

- initiating a European training program for local and regional journalists, to deepen their knowledge about the EU and awareness to EU issues, to improve local and regional media coverage of these issues. Initiating an overall communication campaign to encourage EU citizens to express their voice regarding EU affairs.

These are all relatively innovative ideas, which were not mentioned in the previous three statements examined, or exercised so far. If seriously adopted, they may contribute to enhancement of direct dialogue between EU institutions and citizens. 'Such greater EU level public deliberation and debate, however contentious, is in and of itself politically... legitimating.' (Schmidt, 2017, p. 21).

Yet, if adopted their success would depend on their functioning as forums for sincere substantial dialogue. Also, efficient ways to channel the variety of public opinions on a rich, elaborated agenda to decision makers, who should assess them and translate them into reality, should be figured out. 


\section{Direct democracy?}

The social media is already subverting the national political agendasetting (Caramani, 2017). Successfully handled, intensified direct connection between EU institutions and citizens recommended by $\mathrm{VdB}$ report may thus gradually circumvent the national and regional institutions.

Taken to the extreme, such direct dialogue with EU citizens may establish a modern version of old Athene's 'direct democracy', potentially rendering unnecessary the States, and the entire long debate in the literature over the legitimacy and due form of 'representative democracy' in the EU (e.g. Majone, 1998, 2012; Moravcsik, 2008, 2012). This may appeal to EU institutions, saving the necessity to consult one layer of governance.

However, the States fill an important function in the EU structure, serving the citizens' interests: 'by positioning itself between powerful nonstate actors and self-governing citizens, the state creates spaces of human interaction in which individuals can share meaning with "full freedom and distinctiveness".' (Perju, 2018, p. 404, citing Böckenförde, 2017, p. 94)..$^{15}$ Simultaneously, they serve EU interests by translating EU policy to the national context, enforcing it and serving as a political link between the EU and the citizens: " $\mathrm{a}] \mathrm{s}$ the average citizen is uninterested an uninformed about European integration, he or she relies on domestic cues in order to estimate its costs and benefits.' (Durach, 2012, p. 9). '[T]he more divided a country's elite, and the more elements within it mobilize against European integration, the stronger the causal power of exclusive national identity.' (Hooghe and Marks, 2004, p. 417; see also Stoeckel, 2012).

Thus, 'il]t would be very difficult endeavour for the EU to foster a European identity as strong as the national one because this artificial supranational political object is more distant from citizens' sense of community.' (Durach, 2012, p. 14). Furthermore, perceiving the EU as a threat to the State is a major motivation for Euroscepticism. (Hooghe and Marks, 2004).

For all these reasons, obtaining 'direct democracy' in the near future seems highly unlikely and undesirable.

\section{Different political interests in the EU}

To make it work, the deficiencies of direct communication through the social media, specified in the report, have to be dismantled. This would greatly depend on decisions such as: who in the EU will handle this branch of communication as a whole and how the 'will of the people' will be reliably measured, considering the severe, constant struggles for powers

\footnotetext{
${ }^{15}$ Recognising States' importance, Böckenförde (2017) p. 340) suggested to put 'on hold' advancement in supranational integration to establish their agreed status.
} 
among various EU actors, regarding ideas and policies, authorities and financing (Schmidt, 2017, p. 1), which VdB report conveniently overlooks.

\section{Perpetuating differences or striving for a common identity?}

While strengthening the direct communication channel with EU citizens may boost the notion of democracy (Nicolaides, 2013), creating an accessible platform for expression of all different views, cultures and opinions, others (e.g. Böckenförde, 2017, p. 330) stress the importance of strengthening the common denominator - the 'us consciousness', both at the national and supranational level, believing that in its absence the EU will not survive. While scholars usually view these two approaches as alternatives, VdB report recommends both, but does not elaborate on the substantial ways to obtain them and combine them.

\section{Building a digital community}

Obtaining such results necessitates much more work than the report seems to anticipate. Developing a 'sense of community' in the EU is a slow process, with a centre-periphery distinction between the core members and the joiners of the different enlargement waves. (Scheuer and Schmitt, 2009). While a digital community can facilitate this process, creating an effective and vivid community of such a huge scale necessitates a considerable investment in terms of time, budget and professional effort (e.g. Millington, 2013).

\section{Substance: Building a Common Narrative}

VdB Report highly stresses the necessity to build a common, reliable narrative for EU's purpose and values, with which EU citizens can identify. This message complies with the recognition by some scholars that both the national and supranational levels of EU regime must rely on some homogenous social basis. ${ }^{16} \mathrm{VdB}$ Report does not specify the essence of this narrative. It rather mentions some assisting indications:

It recommends that the narrative developed would be real, not propaganda, new, and would 'meet the double objective of helping the European public gain confidence in 'their' Europe and conveying hope for the future.' (Van den Brande, 2017, p. 7). It has to be 'a values-based narrative to attract the interest of younger generations and provide them with the tools to become the new leaders of the European project' (Van den Brande, 2017 , p. 30), suggesting a new scale of values appealing to them, taking

\footnotetext{
16 There is a controversy among scholars as to the necessary level of homogeneity in the EU: Böckenförde stresses its relativity, while Carl Schmidtt stresses its substenciality/ subtensiveness. Böckenförde (2017a).
} 
into account that '[t]heir sense of solidarity and commitment focuses far more on social activities than on politics.' ${ }^{17}$ (Van den Brande, 2017, p. 20). It has to encompass differentiated narratives covering multiple identities (ibid) and local colour (Van den Brande, 2017, p. 25) in a way that would make EU citizens feel it is 'their' EU, despite national, cultural, lingual and other differences. It has to be coherent and facilitate connections between EU communities. (Emphases added).

In terms of essence, the report suggests to 'give a new impetus to the European integration project by articulating a new narrative following the debate on the Bratislava Declaration, linked to values and political aspirations.' (Van den Brande, 2017, p. 26).

This Declaration (European Union, 2016) expresses the commitment of EU leaders and Member States to ensure the success of the EU project ('functional' approach), depicting a short road-map, indicating most urgent priorities in light of the ongoing crises, e.g. better handling of migration waves while securing EU borders, support Member States in ensuring internal security and fighting terrorism, strengthen EU cooperation on external security and defence, create a promising economic future for all, safeguard the EU's way of life and provide better opportunities for youth.

It reinforces the following elements:

- The EU remains indispensable for the Member States.

- It secured peace, democracy and enabled prosperity in the aftermath of the wars and deep divisions in Europe.

- Determination to make a success of the EU with 27 Member States, building on this joint history.

- The EU is not perfect but it is the best instrument for addressing the new challenges ahead.

This message is not new, but rather characterises the ordinary fearpride 'functional' narrative underlining the Five Presidents Report, the White Paper and the State of Union Address, overlooking the fact that the old economic and war-preventing EU justifications are currently being questioned. (Durach, 2012, p. 48).

It does not suffice to meet the requirements of the $\mathrm{VdB}$ report:

- The statements and the report pay 'lip service' to the need to acknowledge the differentiating narratives, interests and cultures of EU

${ }^{17}$ Scholars have long debated the question whether politics is 'good' or 'bad' for EU development. Some believe that it is necessary to make EU citizens accept EU integration (e.g. Hix and Follesdal, 2006; Zürn, 2006) while others believe it interferes the integration process, due to the need to take into account conflicting interests and preferences (e.g. Moravcsik (2006)). Since recent crises burst, many scholars accept the presence of politics in EU affairs as a fact, E.g. De Wilde and Zürn (2012); Kriesi (2016); Schmidt (2017). 
citizens, but do not specify how to do it. Nor do they suggest a narrative that would facilitate connections between EU communities.

- All five documents (including the Declaration) do not offer any narrative particularly addressing the young citizens, to strengthen their sense of belonging to the EU.

All five documents rely on the false presumption, underlying the 'functional' approach, that while the means the EU takes are controversial, the ('functional') goals are broadly agreed. (Bartl, 2015, p. 5). Even VdB report, acknowledging the importance of these elements, elaborates more on the means of communication than on the substantial discourse.

\section{Conclusion}

This article reflects the current conflict between EU's narrative, stressing the importance of multilateralism ${ }^{18}$ and enhanced market integration for EU's future, and EU sceptics and criticisers' positions, through the analysis of EU's policy statements and attempts to change the latter's opinion.

Ordered by EU Commission, VdB report does not challenge EU's 'functional' aim. Written by a politician, it openly admits EU's political motivation behind a 'technocratic' justification, urging the EU to use tools such as the social media to promote it.

Abstaining from questioning the substance of EU 'functional' goal, its main innovations, compared to former statements examined, focus on the means to promote this goal. Adopting the report's recommendations on this issue may improve citizen's political awareness, which 'affects virtually every aspect of citizens' political attitudes and voting behaviour.' (Zaller, 1990 , p. 125).

The report - more openly than previous statements - acknowledges the need for a new narrative and a new political approach, addressing substantial EU citizens' differences, concerns, desires and expectations, and particularly addressing the young generation, but fails to specify how to obtain it.

Its reliability is watered down by its reflecting of EU's traditional ambivalent approach towards EU citizens and their representing entities, challenging the well- known fact that '[t]rust in the EU is built back home'. (Durach, 2012, p. 16).

To win EU citizens' hearts, as the report recommends, adopting its recommendations should be complemented with a substantial shift from EU's current 'functional' approach and with serious pragmatic efforts to

\footnotetext{
${ }^{18}$ For historical review of multilaterlism's development and importance see: Plesch and
} Weiss (2015). 
listen to EU citizens and take their positions into account. Otherwise, citizens' frustration may be reflected in the 2019 elections (Daniel, 2018), or worse - challenge the EU project altogether.

\section{REFERENCE}

Anderson, P. (2014). The Italian Disaster. London Rev. Books 36(1), 3-16.

Bartl, M. (2015). Internal Market Rationality, Private Law and the Direction of the Union: Resuscitating the Market as the Object of the Political. European Law Journal, $4 / 2015,572-598$.

Bartl, M. (2015a). The Way We Do Europe: Subsidiarity and the Substantive Democratic Deficit. European Law Journal, 4/2015, 23-43.

Böckenförde, E. W. (2017). The Future of Political Autonomy: Democracy and Statehood in a Time of Globalization, Europeanization, and Individualization. In: Künkler, M. and Stein, T. Constitutional and Political Theory: Selected Writings, Vol. 1. Oxford: Oxford University Press, 325-342.

Böckenförde, E. W. (2017a). The Concept of the Political: A Key to Understanding Carl Schmitt's Constitutional Theory. In: Künkler, M. and Stein, T. Constitutional and Political Theory: Selected Writings, Vol. 1. Oxford: Oxford University Press, 69-85.

Böckenförde, E. W. (2017b). Which Path is Europe Taking? In: Künkler, M. and Stein, T. Constitutional and Political Theory: Selected Writings, Vol. 1. Oxford: Oxford University Press, 343-368.

Bugarič, B. and Kuhelj, A. (2018). Varieties of Populism in Europe: Is the Rule of Law in Danger? Hague J. Rule Law 10, 21-33.

Caramani, D. (2017). Will Vs. Reason: Populist and Technocratic Challenges to Representative Democracy. American Political Science Review 111(1), 54-67.

Daniel, A. (2018). Hungarian Prime-Minister Predicts: The End of Liberal Europe in 2019. Channel 20, July 29, [Hebrew]. https://www.20il.co.il/\%D7\%A8\%D7\%94\%D7\%9E-\%D7\%9 4\%D7\%95\%D7\%A0\%D7\%92\%D7\%A8\%D7\%99\%D7\%94-\%7\%97\%D7\%95\%D7\%96\%D7\%94\%D 7\%A 1\%D7\%95\%D 7\%A4\%D 7\%94-\%D 7\%A9\%D 7\%9C-\%D 7\%90\%D 7\%99\%D7\%A8\%D7\%95\%D7\%A4\%D7\%94-\%D7\%94\%D7\%9C\%D7\%99\%D7\%91\%D7\%A8/ (accessed on 6 March 2019).

De Vries, C. E. (2018). Euroscepticism and the Future of European Integration. Oxford: Oxford Scholarship Publishing.

De Wilde, P. and Zürn, M. (2012). Can the Politicisation of European Integration be Reversed? Journal of Common Market Studies 50(1), 137-153.

Dinan, D. (2015). Governance and Institutions: The Year of the Spitzenkandidaten. Journal of Common Market Studies 53(1), 93-107.

Dingwerth, K., Lehmann, I., Reichel, E. and Weise, T. (2015). Democracy Is Democracy Is Democracy? Changes in Evaluations of International Institutions in Academic Textbooks, 1970-2010. International Studies Perspectives 16(2), 173-189.

Durach, F. (2016). Public Opinion Towards the EU: Triumphalism, Euroscepticism or Banal Representations? Cambridge: Cambridge Scholars Publishing.

European Committee of the Regions. (2014). The Charter for Multi-level Governance in Europe. April 3, 2014. https://aer.eu/charter-for-multilevel-governance-in-europe/ (accessed on 6 March 2019). 
European Council. (2017). Council resolution on the structured dialogue and the future development of the dialogue with young people in the context of policies for European cooperation in the youth field, post 2018. OJ C 189, July 1, 2017, 1. http://eur-lex.europa.eu/legal-content/EN/TXT/?qid=1508340782406\&uri= CELEX:32017G0615(01).

European Union. (2016). The Bratislava Declaration. http://www.consilium.europa.eu/ media/21250/160916-bratislava-declaration-and-roadmapen16.pdf (accessed on 6 March 2019).

Fasone, C. (2014). European Economic Governance and Parliamentary Representation. What Place for the European Parliament? European Law Journal 20(2), 164-185.

German Federal Constitutional Court [Bundesverfassungsgericht - BVerfG]. (1993). 89 ENTSCHEIDUNGEN DES BUNDESVERFASSUNGSGERICHTS [BVERFGE], 155.

Gross, D. M. (2006). The Secret History of Emotion: From Aristotle's 'Rhetoric' to Modern Brain Science. London: University of Chicago Press, XXVI.

Habermas, J. (1996). Between Facts and Norms: Contributions to a Discourse Theory of Law and Democracy, translated by Rehg, W. Cambridge: MIT Press.

Habermas, J. (2008). The Constitutionalisation of International Law and the Legitimation Problems of a Constitution for World Society. Constellations, 15(5), 444-455.

Harteveld, E., Van der Meer, T., and De Vries, C. (2013). In Europe We Trust? Exploring Three Logics of Trust in the European Union. European Union Politics 14(4), 542-565.

Héritier, A., Moury, C., Schoeller, M. G., Meissner, K. L., and Motta, I. (2016). The European Parliament as a Driving Force of Constitutionalisation. Report for the Constitutional Affairs Committee of the European Parliament. PE 536.467 http://www.europarl.europa.eu/RegData/etudes/STUD/2015/536467/IPOL_ STU(2015)536467_EN.pdf (accessed on 6 March 2019).

Hix, S. (2008). What's Wrong with the European Union and How to Fix it (Cambridge: Polity Press).

Hix, S. and Høyland, B. (2013). Empowerment of the European Parliament. Annual Review of Political Science 16, 171-89.

Hix, S. and Føllesdal, A. (2006). Why there is a democratic deficit in the EU: A response to Majone and Moracsik. Journal of Common Market Studies 44(3), 533-562.

Hobolt, S. (2015). Public Attitudes toward the Eurozone Crisis. In: Cramme, O. and Hobolt, S. B. (Eds.), Democratic Politics in a European Union under Stress. Oxford: Oxford University Press.

Hochschild, J. L. (2013). Should the Mass Public Follow Elite Opinion? It Depends... Critical Review 24(4), 527-543.

Hooghe, L. and Marks, G. (2004). Does Identity or Economic Rationality Drive Public Opinion on European Integration? Political Science and Politics 37(3), 415-420.

Juncker, J. C. (2015). Completing Europe's Economic and Monetary Union. http://ec.europa. eu/priorities/economic-monetary-union/docs/5-presidents-report_en.pdf (accessed on 6 March 2019).

Juncker, J. C. (2017). The White Paper on the Future of Europe: Reflections and Scenarios for the EU27 by 2025. https://ec.europa.eu/commission/sites/beta-political/files/white_ paper_on_the_future_of_europe_en.pdf (accessed on 6 March 2019). 
Juncker, J. C. (2017a). State of the Union Address. https://ec.europa.eu/commission/ state-union-2017_en; http://europa.eu/rapid/press-release_SPEECH-17-3165 en.htm (accessed on 6 March 2019).

Kriesi, H. (2014). The Populist Challenge. West European Politics 37(2), 379-99.

Kriesi, H. (2016). The Politicization of European Integration. Journal of Common Market Studies 54 (Annual Review), 32-47.

Kumlin, S. (2009). Blaming Europe? Exploring the Variable Impact of National Public Service Dissatisfaction on EU Trust. Journal of European Social Policy 19(5), 408-420.

Lincoln, A. (1863). The Gettysburg Address (Nov. 19, 1863). In: Gienapp, W. (Ed. 2002). This Fiery Trial: the Speeches and Writings of Abraham Lincoln. Oxford: Oxford University Press, 184.

Majone, G. (1998). Europe's 'democratic deficit': The question of standards. European Law Journal 4(1), 5-28.

Majone, G. (2012). Rethinking European integration after the debt crisis. Working Paper no. 3/2012. London: The European Institute, UCL.

https:/www.ucl.ac.uk/european-institute/news/2012/jun/rethinking-europeanintegration-after-debt-crisis (accessed on 6 March 2019).

Millington, R. (2013). How to Build an Online Community: the Ultimate List of Resources. https:/www.feverbee.com/how-to-build-an-online-community/ (accessed on 6 March 2019).

Mańko, R. (2017). Symbolic Violence in Technocratic Law and Attempts at its Overcoming: Politicization Through Humanization? Studia Erasmiana Vratislaviensia $11,31-64$.

Moravcsik, A. (2006). What Can We Learn from the Collapse of the European Constitutional Project? Politische Vierteljahresschrift 47(2), 219-241.

Moravcsik, A. (2008). The Myth of Europe's Democratic Deficit. Intereconomics: Journal of European Public Policy, 331-340.

Moravcsik, A. (2012). Europe after the crisis: How to sustain the common currency. Foreign Affairs 91(3), 54-68.

Muiller, J. W. (2016). Austria: The Lesson of the Far Right. New York: N. Y. Rev. Books.

Munin, N. (2016). The 'Five Presidents Report': Dogs Bark but the Caravan Moves on? European Politics and the Society 17(3), 401-420.

Munin, N. (2016a). Democracy and Financial Crisis Between the Five Presidents Report and the Brexit: In Search for a New Way? International and Comparative Law Review 16(2), 7-28.

Munin, N. and Matthee, M. (2018). The Future of the EU: Rhetoric in Service of Commission's Agenda? Journal of Jurisprudence and Legal Practice XXVI(1), 5-23.

Nicolaides, K. (2013). European Demoicracy and Its Crisis. Journal of Common Market Studies 51(2), 351-369.

Paris, D. (2017). Constitutional courts as European Union courts: the current and potential use of EU law as a yardstick for constitutional review. Maastricht Journal of European and Comparative Law 24(6), 792-821.

Plesch, D. and Weiss, T. G. (2016). 1945's Forgotten Insight: Multilateralism as Reality Necessity. International Studies Perspectives 17(1), 4-16. 
Perju, V. (2018). On the (De-)Fragmentation of Statehood in Europe: Reflections on Ernst-Wolfgang Böckenförde's Work on European Integration. German Law Journal 19(2), 403-434.

Pech, L. and Scheppele, K. L. (2017). Illiberalism Within: Rule of Law Backsliding in the EU. Cambridge Y.B. Eur. Legal Stud. 19, 3-47.

Scharpf, F. W. (1999). Governing in Europe. Oxford: Oxford University Press.

Scharpf, F. W. (2013). Monetary Union, Fiscal Crisis and the Disabling of Democratic Accountability. In: Schäfer, A. and Streeck, W. (Eds.), Politics in the Age of Austerity. Cambridge: Polity.

Scheuer, A. and Schmitt, H. (2009). Dynamics in European Political Identity. Journal of European Integration 31(5), 551-568.

Schmidt, V. A. (2006). Democracy in Europe. Oxford: Oxford University Press.

Schmidt, V. A. (2017). The Political Dynamics of EU Governance in Response to Crisis: Towards More or Less EU Legitimacy? http://www.democratic-anxieties.eu/ wordpress/wp-content/uploads/2017/10/Berlin-Paper-EU-political-dynamics-andlegitimacy.pdf (accessed on 6 March 2019).

Sigalas, E. (2010). The Role of Personal Benefits in Public Support for the EU: Learning From the Erasmus Students. West European Politics 33(6), 1341-1361.

Sigalas, E. (2010a). Cross-Border Mobility and European Identity: The Effectiveness of Intergroup Contact During the ERASMUS Year Abroad. European Union Politics 11(2), 241-265.

Shuster, S. (2016). The U.K.'s Old Decided for the Young in the Brexit Vote. Time, June 24, http://time.com/4381878/brexit-generation-gap-older-younger-voters/ (accessed on 6 March 2019).

Stoeckel, F. (2012). Ambivalent or Indifferent? Reconsidering the Structure of EU Public Opinion. European Union Politics 14(1), 23-45.

Terhalle, M. (2016). Transnational Actors and Great Powers During Order Transition. International Studies Perspectives 17(3), 287-306.

Tsoukalis, L. (2016). In Defense of Europe. Oxford: Oxford University Press.

Weiler, J. and Trachtman, J. (1996-1997). European Constitutionalism and Its Discontents. NW. J. INT'L \& BUS. 17, 354-397.

Zaller, J. (1990). Political Awareness, Elite Opinion Leadership, and the Mass Survey Response. Social Cognition 8(1), 125-153.

Zaller, J. (1992). The Nature and Origins of Mass Opinion. New York: Cambridge University Press.

Ziętek, M. (2012). Europejskie prawo konsumenckie jako wyraz technokratycznej koncepcji prawa umów. In: Jagielska, M., Rott-Pieterzyk, E. and WiewiórowskaDomagalska, A. (Eds.), Kierunki rozwoju europejskiego prawa prywatnego [Directions of Development of European Private Law], Warszawa: CH Beck, 275.

Zuirn, M. (2016). Opening up Europe: Next Steps in Politicisation Research. West European Politics 39(1), 164-82. 